\title{
THE A N A LS
}

AND

\section{MAGAZINE OF NATURAL HISTORY.}

\author{
[FIFTH SERIES.]
}

No. 113. MAY 1887.

XLI.-Parasitic Castration, and its Influence upon the External Characters of the Male Sex, in the Decapod Crustacea. By Prof. A. Giard *

"Whatever may be said concerning the advantages to the experimenter of having no preconceived idea, it is proved by innumerable examples that one often misses those phenomena which one did not expect to meet with, and that observation is much more intense and much more fruitful when the investigator knows beforehand what he ought to find, and strives pertinaciously to find it, notwithstanding want of success at the outset" $\dagger$.

In these words, when commencing his course last year, one of the masters of biology in France expressed himself, and there never has been a statement more useful to repeat. To be convinced of this we have only to run through the memoirs produced for some time past in most of our zoological laboratories. The triumph of the school of Cuvier is now-a-days complete; the intolerant dogmatism and the exclusively empirical tendencies of those who occupy the chairs of authority no longer permit any general views. Im-

* Translated by W. S. Dallas, F.L.S., from a separate copy, furnished by the author, of the paper in the 'Bulletin Scientifique du Nord,' sér. 2, année x., 1887.

† Marey, "Les Lois de la Mécanique en Biologie," 'Revue Rose,' 3rd July, 1886, p. 3.

Ann \& Mag. N. Hist. Ser. 5. Vol. xix. 
bedding and sectioning, describing as closely as possible a microscopic preparation, detailing to the public the little misadventures of a badly-conceived histological cuisine are the things which constitute a presentable thesis; as to the conclusion of the memoir, that must be impressed with the greatest reserve. It will be remarked, for example, that the Brachiopoda are probably Brachiopoda, and that, in spite of all the recent works upon the Tunicata and the Bryozoa, the subkingdom Mollusca is still extant. And nevertheless the enormous mass of facts which is every day being accumulated by the naturalists of the whole world renders more and more necessary the employment of the synthetic method, without which science is a chaos. Moreover, theoretical ideas, far from being, as has been asserted, a source of error, very often enable us to correct old erroneous and imperfect views, and to render available peculiarities which, without them, would have passed unnoticed.

The present note, I think, will be a fresh demonstration of the aphorism enunciated by Prof. Marey.

In the course of Iast summer, at Concarneau, I had the opportunity of studying a Sacculina parasitic upon Stenorhynchus phalangium, Pennant. This Sacculina had already been indicated, without description, by Fraisse, who met with it at Naples; I called it Sacculina Fraissei, in honour of that zoologist. It appears to be rather common. Although such statistics are very liable to vary and only constitute the result of a rough approximation, I estimate at about one in fifty the number of Stenorhynchi infested by this Rhizocephalan among those captured in the Bay of La Forest.

Sacculina Fraissei is easily distinguished from the other species of the same genus by its external form and its organization. It is entirely concealed in the sort of case formed by the tail of the crab and the sternal plastron. Its outline is cordiform. The cloacal aperture is nearly sessile, and irregularly triangular in young individuals. The chitinous ring which surrounds the peduncle is very simple and not strongly marked; the peduncle is hollow; the roots are thicker and more irregularly branched than those of $S$. carcini; the colleteric glands annexed to the ovary are well developed and situated at the sides, towards the upper third of the height. The orientation is the same as that of S. carcini. The ovoid, or nearly spherical, testes are situated at the median part of the posterior half of the ovaries, nearly in the centre 
of figure of the parasite; each of them gives origin to a long deferent duct which reaches the posterior margin of the ovary and turns round it to open in the suprapeduncular region. S. Fraissei therefore belongs to the group of the mesorchidean Sacculina, the type of which is Sacculina corculum, Kossmann, which is parasitic upon Atergatis floridus. As in the case of the parasite of Carcinus manas, the Sacculina arrives at its complete formation during the period of reproduction of the crab-that is to say, in the present case, during the months of June and July*.

Since the year 1873, when I began to study the Rhizocephala, I have found, upon the Crustacea of our shores, about twenty species of Sacculince, several of which are new to science or still only imperfectly known. Hitherto I have published nothing upon these animals. Why then have I attached particular importance to the discovery of the Sacculina of the Stenorhynchus, and devoted myself to a more active investigation of that parasite? It is because Fraisse had made an observation upon a species also parasitic upon an Oxyrhynchan, namely the Sacculina neglecta of Inachus scorpio, which, if correct, would possess great interest. Fraisse, in fact, asserted that the males of Inachus scorpio are never infested by the Sacculina, and he attributed this immunity to the narrowness of their abdomen; he says:"The males of Inachus, according to my observations, are never infested by parasites, probably on account of the different form and the smallness of their abdomen."

The sexual dimorphism of Stenorhynchus being just as marked as that of Inachus, it seemed likely that Sacculina Fraisse $i$ would present the same ethological peculiarity as Sacculina neglecta, and would infest only the females. The confirmation of Fraisse's observation would have been a fresh argument in favour of the theory of the local fixation of the embryos of the Rhizocephala in opposition to the curious hypothesis of the migration of the larvæ, recently put forward by M. Y. Delage. Seeing that in all the species of Decapods, all more or less dimorphic, in which I had met with Sacculince, I had never noticed even a comparative immunity of the male sex, Fraisse's supposed discovery seemed to me to prove too much. Nevertheless one could not regard it à priori as

* My excellent friend Prof. Marion sent me, some years ago, a Sacculina parasitic upon Stenorhynchus agyptius, M.-Edw., which is evidently very nearly allied to S. Fraissei. I designate it S. Fraissei, var. agyptia. The Stenorhynchus which bore it came from the muddy bottom to the east of the port of Algiers, between the gasworks and the Aga's baths.

+ P. Fraisse, "Die Gattung Cryptoniscus, F. Müller," 1877, p. 23, note 3 . 
erroneous, for it seemed to have a relation to another fact of the same nature long since indicated in the case of other parasites. As long ago as 1837 Rathke wrote :- "Mirabile dictu, Bopyri omnia quæ vidi exempla-vidi autem eorum plures centurias-solummodo in Palæmonibus feminis repereram, licet in manus meas non pauciores horum animalium mares, quam feminæ incidissent" ('De Bopyro et Nereide,' p. 18). Choice in fixation does not seem to be theoretically more impossible in the ease of the Sacculina than in that of the Bopyri.

However this may be, for several days I carefully examined the numerous Stenorhyneti which every sweep of the trawl brings up from the bottom of the Bay of La Forest. At the first glance the superficial examination that one could make on board the boat seemed fully to confirm Fraisse's opinion. On the first day of dredging I returned to the laboratory quite convinced that I brought back only female Stenorhynchi bearing Sacculince. This crab is so transparent that, even without lifting the tail, we can perfectly distinguish the yellowish tint of the parasite through the integuments of its host.

As in Stenorhynchus the number of males greatly exceeds that of the females, the apparent immunity of the former became still more singular. But a eareful examination of these Crustacea soon revealed some very eurious facts, although very different from that indicated by Fraisse.

In the infested females the influence of the parasite, which displays itself internally by the abortion of the ovules, betrays itself externally by a profound modification of the four pairs of ovigerous feet on the abdomen. These appendages are very inferior in size to the normal state, sometimes reduced to small scarcely plumose ares; and we cannot ascribe their atrophy to wearing caused by the friction of the Sacculina. In fact, I have ascertained that in adult females upon which the recently evaginated Sacculina was still of very small size and removed from all contact with the ovigerous feet, the latter already presented the dwarfish and stunted aspect of aborted organs. Here therefore there is no mechanical action, but a remarkable fact of correlation of growth.

I soon observed infested Stenorhynchi, apparently quite similar to the preceding, in which the ovigerous feet did not exist at all; but in these cases it was easy to find, between the parasite and the sternal surface of the crab, the copulatory styles, greatly reduced in size it is true, and, further, the position of the genital apertures was different. In one word, these individuals were males in which the tail had the width 
and all the external characters of the female appendage, and seemed to be arranged to protect the parasite as perfectly as it protects the eggs in the other sex.

Moreover, the secondary sexual characters of these infested males were likewise modified in the same direction as the primary characters. The chelæ of the first pair of legs, instead of being strongly developed and projecting far beyond the head as in the normal males, were feeble and reduced as in the female sex. All these peeuliarities are the more striking as in its ordinary state Stenorkynchus is one of the Brachyurous Decapods in which the sexual dimorphism is most accentuated. A drawing of these males, castrated by the parasite, seems to be absolutely useless, as it would be confounded with the classical figures given of the female sex. The number of these males, moreover, is more restricted than that of the females (about one to six aecording to my statistics). In presence of this result I have every reason to think that Fraisse, being more particularly engaged in the investigation of Cryptoniscus, contented himself with a too rapid examination of the Inachus scorpio infested by Sacculina neglecta, and that in this Oxyrhynchan, as in Stenorhynchus, the male sex is not free from the attacks of the Bhizocephalan.

\section{II.}

Since 1873, I may say without exaggeration that thousands of Carcinus monas bearing Sacculince have passed under my eyes. More recently M. Yves Delage, on his part, has examined a respectable number of these animals. He has done this with a very legitimate but particularly lively desire to see something that I had not seen. In other countries Kossmann has also studied the Rhizocephala with much care and success. Nevertheless meither Kossmann, nor Delage, nor myself had noticed a very important fact, which one cannot help seeing when, instead of looking, one observes. This fact may be enunciated as follows:-When a young male Carcinus mænas is infested by a Sacculina it acquires, in part, the external sexual characters of the female sex. The resemblance may be carried so far as to cause for a moment a difficulty in the determination of the sexes if we neglect to lift the caudal appendage.

Even last year, when I announced to the Academy of Sciences the curious observations which I had made upon the Sacculina of Stenorhynchus *, I still regarded that type as exceptional, and thought that in most of the Decapod Crusta-

* Comptes Rendus, July 5, 1886, p. 84 ; 'Annals,' ser. 5, vol. xviii. p. 165. 
cea the atrophy of the male genital glands, caused by the presence of a Sacculina, was unaccompanied by any modification of the external sexual characters. Nevertheless I had a vague recollection of the embarrassing cases to which $I$ have alluded above. Hence, on my arrival at Wimereux during the vacation, profiting by the circumstance that the Sacculina was comparatively abundant that summer, I examined a great number of infested specimens of Carcinus monas, and I soon found it easy to recognize, and to demonstrate to my pupils, the effects of parasitic castration upon the young male crabs. So true is it that, as Marey says, "observation is much more intense and much more fruitful when the investigator knows beforehand what he ought to find, and strives pertinaciously to find it, notwithstanding want of success at the outset."

The external sexual characters of the Brachyurous Decapod Crustacea are too well known for us to delay much in describing them. It is well known that the principal one is that the tail (abdomen) of these animals is generally broad and oval in the female, while it is narrow and trapezoidal or triangular in the male sex. This abdomen is composed of seven somites, of which the first two (1 and 2) bear the copulatory styles in the male, while in the female the somites $2,3,4$, and 5 are furnished with the plumose feet destined to support the ova. Lastly, in a certain number of species, notably in Carcinus monas and in Portunus, the somites 3, 4, and 5 are intimately soldered together in the male in such a way that the tail appears to be formed only of five segments, thus, $1,2,3,4,5,6$, and 7 .

Grobben has pointed out that the coalescence of the segments $3,4,5$ in the male sex does not occur in certain Cyclometopa (Eriphia spinifrons, Pilumnus hirtellus), and that even in other groups of Brachyura (Notopoda, Oxystomata, Oxyrhyncha, Catometopa) side by side with forms in which there are five segments in the abdomen of the male we find others which have retained the seven primitive somites. Whence it may be concluded that the coalescence has been produced independently in the various sections of the Brachyura, and that it probably constitutes an arrangement serviceable in the act of copulation. Lastly, the chelæ are generally more developed in the male sex.

All these external sexual characters disappear more or less when the crab is rendered sterile by the presence of a parasite; the copulatory styles and the ovigerous feet are frequently more or less atrophied, but always much less so than in Stenorhynchus. The modification bears especially upon the general form of the tail, which in the male sex takes on the 
appearance which we here reproduce (fig. III.). The whole organ, without quite attaining the width which it presents in the female sex, is nevertheless much wider than in the normal

Fig. I.

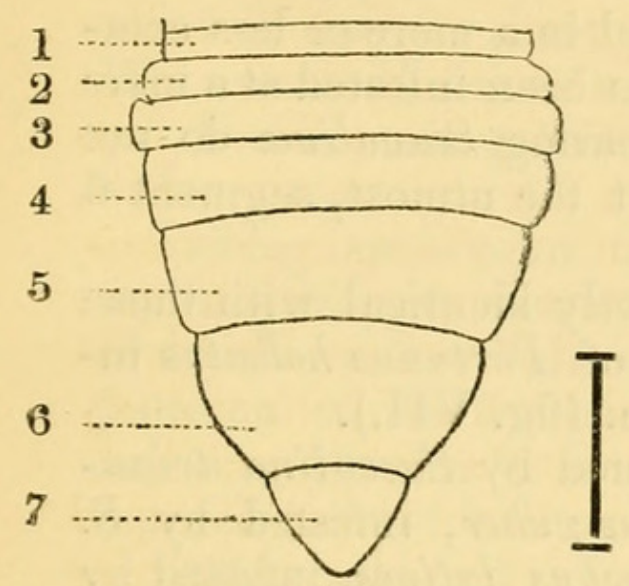

Fig. III.

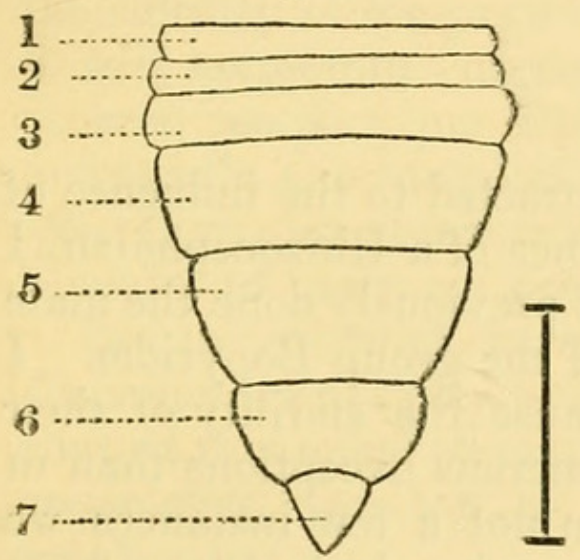

Fig. V.
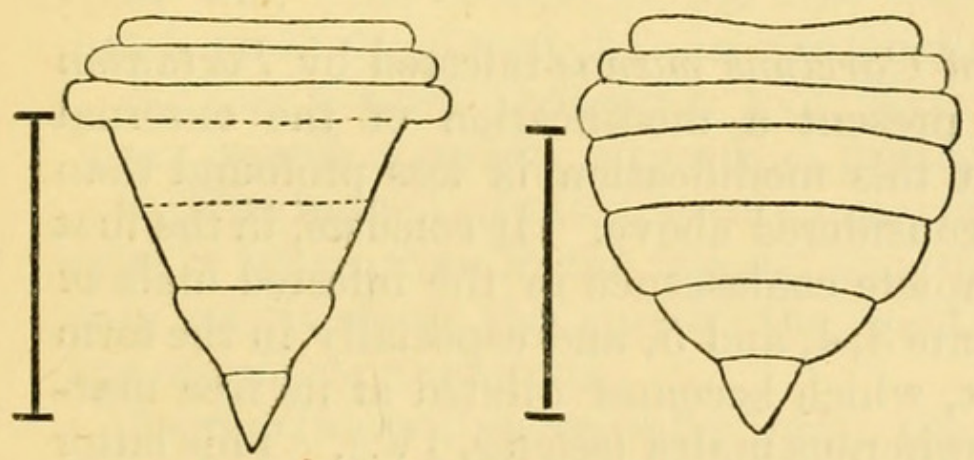

Fig. VI.

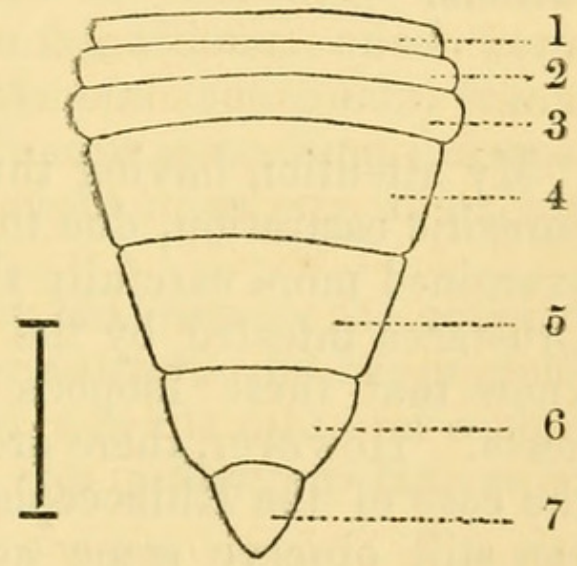

Fig. VII.

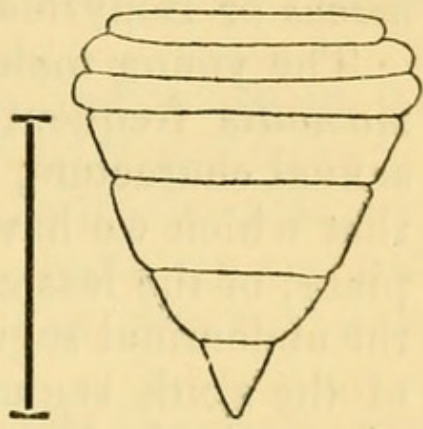

Figs. I.-III. Abdomen of Carcinus manas.-I. Female. II. Male (normal). III. Male infested by Sacculina. IV. Male infested by Entione. Figs. V.-VII. Abdomen of Portumus holsatus.-V. Male (normal). VI. Female. VII. Male infested by Sacculina.

males. The segments 3,4 , and 5 are still generally soldered together or very slightly movable, but their outlines are well marked and they seem to be quite distinct; segment 3 does 
not project so much laterally beyond the following segments. Segment 6 (that which in the Macrura bears the uropods) is rounded on its free margins and presents nearly the form of a semicircle instead of being trapezoidal as in the ordinary male.

All these modifications are produced in a more or less complete fashion according as the crab has been infested at a more or less advanced age; old males bearing Sacculince do not differ at all from normal males, or, at the utmost, segment 6 is slightly dilated at its margins.

I have observed modifications exactly identical with those of Carcinus monas in young males of Portunus holsatus infested by Sacculina Andersonii, sp. n. (fig. VII.).

The males of Cancer pagurus infested by Sacculina triangularis, Anderson, those of Portunus puber, infested by $S$. Priei, sp. n., and those of Platyonychus latipes, infested by S. Betencourti, sp. n., present much less considerable modifications.

\section{III.}

My attention having thus been attracted to the influence of parasitic castration, due to the presence of a Rhizocephalan, I examined more carefully than I had previously done the male Crustacea infested by the Isopods of the group Bopyridæ. I knew that these Isopods usually cause the sterility of their hosts. However, there are more numerous exceptions than in the case of the Rhizocephala, and in not a few instances we can still observe some activity, imperfect it is true, of the male or female genital glands of the Decapods bearing Entoniseus or Bopyridæ.

The young males of Carcinus mcenas infested by Portunion manadis frequently present a modification of the external sexual characters, but this modification is less profound than that which we have considered above. It consists, in the first place, of the less complete coalescence in the infested male of the abdominal segments 3,4 , and 5 , and especially in the form of the sixth segment, which becomes dilated at its free margins as in the Sacculiniferous males (see fig. IV.). This latter peculiarity is very interesting. In the males bearing Sacculince, the tail being gradually raised by the parasite, it might be thought that the dilatation of the sixth somite was due to the circumstance that this segment was no longer confined within the groove hollowed out in the sternal part of the carapace of the crab. But the same explanation cannot be given in the case of the male bearing Entoniscus, and one is torced to assume that this modification of the sixth somite is 
a phenomenon of correlation of growth without any direct mechanical cause.

I should have liked to pursue the observation of these curious facts in other species of Decapods infested by Entione; unfortunately these parasites are rare, and Platyonychus latipes, which is very frequently infested by Portunion Kossmanni at Wimereux, is not well adapted for the investigation of this question in consequence of the narrowness of the abdomen in both sexes.

Taking into account the facts which we have just discussed we may inquire whether the peculiarity noticed by Rathke, to which we have already referred, namely the exclusive infestation of the female prawns by Bopyrus squillarum, may not be explicable by a mistake analogous to that which we at first fell into with regard to the Sacculina of Stenorhynchus.

Rathke also first indicated, and all subsequent authors have confirmed this statement, that the presence of a Bopyrus caused the sterility of the prawn which bore it. He says :- "Haud minus memoratu dignum hoc mihi videter, quod neque eo anni tempore quo Palæmones ova sua (sub cauda) fovent, neque ullo alio tempore inter ea horum animalium exempla, quæ Bopyrum exceperant, ullum inveni cujus ova ita exculta fuissent, ut partu edi potuissent "*.

But the external characters which distinguish the sexes in Palcemon are not very striking. Grobben + , who has recently studied this question pretty completely in the case of Palcemon rectirostris, ascribes to the male the following differential peculiarities :-

1. Its size is smaller.

2. The inner branch of the first pair of abdominal feet is much more developed than in the female.

3 . The second abdominal foot bears on the inside of its inner branch a styloid appendage furnished with stiff hairs ł.

4. The branch of the first antennæ which bears the olfactory setæ is larger than in the female, and that absolutely and not only relatively to the size of the body. The olfactory setæ are also more numerous.

As the Bopyridæ generally infest the young Decapods, the first character (1) derived from the size cannot be of any use in the question now under consideration. The other characters consist in the greater development in the male of organs

* Rathke, De Bopyro et Nereide, 1837, p. 18.

† Grobben, 'Beiträge zur Kenntniss der männlicher Geschlechtsorgane der Dekapoden' (Vienna, 1878), pp. 76, 77, 79.

$\ddagger$ Heller further indicates a second and smaller inner appendage, but he has mistaken for this the retinaculum ('Die Crustaceen des südlichen Europa,' Vienna, 1863). 
which exist in a less degree in the female. It is reasonable to suppose that the atrophy of the genital glands must have an influence upon the development of these external organs. Lastly, as it is very probable that Rathke did not undertake a complete dissection of the infested prawns which he examined, and that he no doubt contented himself with a determination of the sexes by the most prominent external characters, there is room for an inquiry whether this determination may not have been rendered erroneous by the influence of the parasite itself, and whether Rathke did not regard as females males in which the presence of the Bopyrus had hindered the manifestation of the external sexual characters.

This very interesting verification might be quickly made in localities where Bopyrus is abundant. I may indicate as a particularly favourable spot for this investigation the little port of St. Vaast-la-Hougue. Some years ago (in 1875) I there found Bopyrus squillarum in great abundance. Unfortunately at that time the question under discussion had not yet arisen, and I paid no attention to the matter.

Besides the preceding cases a single example of parasitic castration is noted elsewhere among the Crustacea, namely that of a Copepod, Cyclops tenuicornis, infested by larvæ of Distoma, and in consequence presenting embryonic characters during its whole life *.

\section{IV.}

A case of parasitic castration absolutely comparable to that which we have just studied in the Decapod Crustacea has been indicated by Perez in the Hymenopterous insects of the genus Andrena infested by Stylops $\dagger$. The communication of the learned professor of Bordeaux is most interesting, and does not seem to have been sufficiently appreciated by French and foreign zoologists. Hence we think it will be serviceable to reproduce here the summary of it, which was given in the 'Revue internationale des Sciences.'

Having remarked that certain species of Andrena constantly bear a parasite, and having closely examined these species, Perez recognized that they are only abnormal forms of other species; and this led him to study the anatomical modifications which, in the bee, are correlative with the presence of a parasite.

* Herrick, "Heterogenetic Development in Diaptomus," "American Naturalist,' vol. xviii.

† Perez, "Des effets du parasitisme des Stylopes sur les Apiaires du genre Andrena" (Soc. des Sci. phys. et Nat. de Bordeaux, 12th June, 1879 ; ' Revue internationale des Sciences,' tome iv. p. 281). 
In general a stylopized bee has the head smaller than a normal individual of the same species, the abdomen more globose, the integument of this latter organ sometimes discoloured, its puncturing less strongly marked, its villosity more abundant and longer upon the last segments, and presenting a marked tendency to acquire a golden-red tinge towards the extremity in those species in which the hairs of this part are fulvous or even brown. Lastly, which is even more remarkable, the female has the hind legs more slender, and their brush more or less reduced, sometimes wanting; and in the species in which the male has the face white or yellow the female acquires spots of this colour ; the sting itself becomes smaller. On the other hand, the male sometimes loses the proper coloration of his face, and thus becomes more like the female. Each sex thus loses more or less the attributes which characterize it and tends more or less to acquire those of the opposite sex.

It must be added that a stylopized female is never seen bearing pollen on the hind legs; she plunders the flowers, but only for her own nourishment, and not to collect anything. She therefore appears to be destitute of the reproductive function, as she is deprived of certain characters which are the external signs of it.

It was natural to deduce from these facts that by its presence the Stylops causes the atrophy of the internal genital organs. Some authors who have paid attention to parasites have, in fact, noted in passing the atrophy of the genital organs of the host. But these data are very vague and it was necessary to check them. M. Perez ascertained that in a stylopized female Andrena the ovarian tubes are completely arrested in their development and the ova never attain their normal evolution; the stylopized female is unfitted for reproduction. In the male the atrophy usually affects only the testis of the side on which the parasite is situated; the sperm-cells become segmented, but without producing: spermatozoids. But the testis of the opposite side attains its normal volume and is found to be distended by a great quantity of semen. The stylopized male may therefore still copulate with effect; the stylopized female probably never copulates - at any rate she cannot lay fertile eggs.

According to Perez this atrophy of the genital organs is a simple arrest of develepment and appears to be chiefly an effect of the pressure due to the presence of the parasite, whose body almost entirely fills the abdomen *.

* To the examples of parasitic castration above enumerated we may further add the very interesting case of the North-American squirrel, 
What conclusions can we draw from the observations which we have just summarized?

Keeping for the moment to the facts taken in themselves, without attempting to inquire into their primary cause, and considering them in their maximum state, that is to say, such as we observe in Stenorhynchus phalangium, we shall see at once that the parasite, when fixed upon a male crab, is much better protected than it would have been if the male had not undergone the modification already described. As, however, this transformation does not take place unless the crab is infested when quite young, at a time when the sexual differentiation has not yet been produced, it follows that natural selection must have determined a more and more precocious fixation of the parasite*. Hence it happens that the Sacculince of the Oxyrhyncha (1) always infest young crabs, and (2) cause a more complete atrophy of the copulatory styles and ovigerous feet.

In the Brachyura of which the sexual dimorphism is less accentuated the protection afforded to the parasite by the modified abdomen of the male is less efficacious; consequently natural selection plays a less active part, and we pretty frequently observe the infestation of old individuals. Moreover, even in case of early infestation, the modification of the male sexual characters is less considerable.

If we now seek to understand the mode in which the modifications of the external sexual characters of the Decapods are connected with parasitic castration, several explanations occur to the mind and must be examined in their turn.

1. It may be supposed that these modifications are useful to the infested crab, and, in consequence, have been gradually developed by natural selection.

It may seem strange, à priori, to invoke natural selection, and consequently heredity, to explain phenomena which are associated with the sterility of the animals which manifest them; but we must not forget that this sterility is only temporary, that it ceases with the existence of the parasite, and that it is not impossible that a crab which has borne a Sac-

Tamias Lysteri, Rich., which, according to Asa Fitch, is often castrated by an Estrid larva, Cuterebra emasculator, Fitch, which resides in the testicular sac. We would suggest to our American confrères the complete investigation of this parasite and of the effects which it produces.

* Of course at present we have to do only with natural selection as applying to the parasite. 
culina may recover and become the progenitor of a numerous family.

It may also appear paradoxical to say that it is advantageous to the crab to thoroughly protect its parasite. Nevertheless it is easy to convince one's self, by examining a crab bearing a Sacculina, that every excitation of the parasite produces a contraction the recoil of which is very painful to the crab. The more the Sacculina is sheltered the less the crab must experience pangs resulting from the contraction of the Rhizocephalan when irritated by external objects. And, further, if the Sacculina happens to be severely wounded, it will die and become decomposed on the spot, often causing the death of the crab, whose viscera are affected by the putrefaction of the roots of its enemy. On the other hand, if the Sacculina grows old, suitably protected, it has still an existence much shorter than that of its host, and when it dies its roots in time undergo a sort of dry degenerescence which does not seem at all to place the life of the crab in danger.

A priori therefore we cannot entirely reject the influence of natural selection in the transmission of the capacity on the part of the male crabs of acquiring certain modifications ; but we nevertheless think that this explanation must be discarded upon considerations of comparative physiology.

It has long been known that the castration of the males of mammals and birds results in giving to the animals subjected to it the secondary sexual characters of the female sex. Perhaps it would be more correct to say that, in these cases, as in that under consideration, castration prevents the development of the male sexual characters. However this may be, in geldings and capons the sterility is complete and definitive. Now the modifications which they present are completely of the same nature as those which we have indicated among the Crustacea. We have therefore to find an explanation which may apply to all the cases.

2. We might seek this explanation in what Darwin has called "latent characters." Of these it is precisely the secondary sexual characters which furnish the best example. "In every female," says Darwin *, "all the secondary male characters, and in every male all the secondary female characters, apparently exist in a latent state, ready to be evolved under certain conditions. It is well known that a large number of female birds, such as fowls, various pheasants, partridges, peahens, ducks, \&c., when old or diseased, or when operated on, partly assume the secondary male characters of their

- 'Variation of Animals and Plants,' vol, ii. p. 51. 
species. In the case of the hen pheasant this has been observed to occur more frequently during certain seasons than during others [Yarrell, Phil. Trans. 1827 ; Dr. Hamilton, P. Z. S. 1862]. A duck ten years old has been known to assume both the perfect winter and summer plumage of the drake. Waterton [Essays, 1838] gives a curious case of a hen which had ceased laying and had assumed the plumage, voice, spurs, and warlike disposition of the cock; when opposed to an enemy she would erect her hackles and show fight. Thus every character, even to the instinct and manner of fighting, must have lain dormant in this hen as long as her ovaria continued to act*. The females of two kinds of deer, when old, have been known to acquire horns."

Lastly, every one knows that in many women after the cessation of menstruation the chin and upper lip become clothed with a regular beard, a phenomenon the relation of which to the development of the male plumage in old hen pheasants cannot be denied.

"On the other hand," says Darwin (l.c.), "with male animals, it is notorious that the secondary sexual characters are more or less completely lost when they are subjected to castration. Thus, if the operation be performed on a young cock, he never, as Yarrell states, crows again; the comb, wattles, and spurs do not grow to their full size, and the hackles assume an intermediate appearance between true hackles and the feathers of the hen. Cases are recorded of confinement alone causing analogous results. But characters properly belonging to the female are likewise acquired; the capon takes to sitting on eggs, and will bring up chickens; and, what is more curious, the utterly sterile male hybrids from the pheasant and the fowl act in the same manner, "their delight being to watch when the hens leave their nests and to take on themselves the office of a sitter.' That admirable observer Réaumur asserts that a cock, by being long confined in solitude and darkness, can be taught to take charge of young chickens; he then utters a peculiar cry, and retains during his whole life this newly acquired maternal instinct. The many well-ascertained cases of various male mammals giving milk show that their rudimentary mammary glands retain this capacity in a latent condition."

We have cited textually these passages from Darwin, of which the conclusion is that " in many, probably in all, cases, the secondary characters of each sex lie dormant or latent in

* “ Isid. Geoffroy St.-Hilaire in his ' Essais de Zool. Gén.' (1842), has collected such cases in ten different kinds of birds. It appears that Aristotle was well aware of the change in mental disposition in old hens." 
the opposite sex, ready to be evolved under peculiar circumstances."

Examples of a similar abnormal development of the characters of one sex in the opposite sex are not unknown among. the Crustacea. Grobben * has several times met with females of Astacus fluviatilis in which the first pair of abdominal feet were constructed as in the male. The ovaries were well developed, and these females bore ova upon the other feet. Grobben interprets the fact as a simple transfer of the characters of one sex to the other, which, he adds, is not uncommon in the animal kingdom.

E. von Martens bas noted the presence of female genital apertures in the male of Astacus plebeius $\dagger$. Hilgendorf has likewise ascertained the presence of rudimentary female genital orifices upon the third pairs of feet of the males of certain Crustacea + .

We may remark that in the case of the crabs infested by Sacculince there is not in reality, as we have already pointed out, any manifestation of female characters in the male sex, but rather an absence of the development of the male characters; the animal remains in a young stage, not sexually differentiated, but acquiring a somewhat larger size. This is also, in our opinion, what occurs in castrated mammals and birds. While the females whose ovaries have been destroyed or no longer function acquire the positive characters of the male sex (horns, spurs, hackles, \&c.), the castrated males are modified especially in this direction, that they do not acquire the attributes of their sex. It is true that it may be remarked that in the cases cited by Darwin, as in that of the Sacculiniferous Crustacea, it is the female that most closely approaches the stock-form and presents the fewest secondary sexual characters. Nevertheless one does not see why the female Brachyura furnished with Sacculince do not lose their ovigerous feet which have become useless.

3. The fact that in cases of infestation there is really no manifestation of female characters in the male sex, or of male characters in the female sex, leads us to attribute the modifications of which we have been speaking to a simple arrest of development of the external characters of the two sexes, an arrest of development which is more noticeable in the male, because in that sex the secondary sexual characters are, in the normal state, much more developed than in the female.

* 'Beiträge zur Kenntniss der männlicher Geschlechtsorgane,' p. 83.

$\dagger$ Senckenb. Ges. naturf. Freunde, 1870, p. 1.

I Die von Herrn W. Peters in "Mozambique gesammelten Crustaceen," Monatsb. Akad. Berl. 1878, pp. 782-851. See also Tagbl. der Versamml. Deutscher Naturf., Cassel, 1878. 
In support of this view we may cite here some very correct ideas put forward by Isid. Geoffroy Saint-Hilaire in his 'Zoologie générale' with regard to female birds in male plumage. He says :-

"We may assume theoretically the existence in most species of birds not of a brilliant plumage proper to the male and of a dull plumage proper to the female, but, in general, of two plumages, one imperfect, belonging especially to the young, the other perfect, which the males acquire very early and which the females also tend to acquire, but at a much more advanced age and under certain peculiar circumstances $" *$.

And further on he adds :- "It has been said that the young of both sexes have the plumage of the fernale; but is this statement perfectly correct? Is it really the case that the male in his youth has the permanent plumage of the female? Or, which is theoretically very different, is it not that the female retains more or less completely the plumage of youth, which, as regards her colours, is arrested in development and does not arrive at the conditions characteristic of the perfect state of the species?" (l. c. p. 492).

Further, "The old female in the course of those remarkable phenomena which tend to render her more and more like the male, seems to tend to pass through all the same phases which the male pheasant traverses in his youth. A female, when her laying is about to cease or has just ceased, and a young male are in conditions which may be compared in many respects. Both have the same plumage, the imperfect plumage ; both will have again, at a more or less distant period, the same plumage, the perfect plumage of the species. The same change must therefore take place in both cases, since the starting-point is the same, and the old female and the young male tend towards the same end. But the changes take place with very unequal rapidity in the one and in the other; one requires several years, a single year suffices for the other. Moreover the order in which the change is effected is not exactly the same. It will be sufficient to compare the young males preserved in all our museums, with the details that I have given of the old females, to see that in the two cases the change takes place in a different manner. It is never possible to say of an old hen pheasant in which the change has commenced that she has exactly the plumage of a young cock pheasant of such or such an age. It is therefore by two different ways that nature advances in the one case and the other towards similar final results " (l.c. pp.507, 508).

* 'Essai de Zoologie générale,' 1841, p. 492. 


\section{VI.}

Generally we think that the modifications due to parasitic castration must be assimilated to those which are the result of progenesis. We say that there is progenesis when in an animal sexual reproduction occurs in a more or less precocious manner, that is to say, when the sexual products (ova or spermatozoids) are formed and matured before the creature has attained its full development. As examples may be cited the axolotls and larva of Tritons, which, the former normally, the latter occasionally, oviposit while they still possess their branchiæ.

Very often progenesis affects only one sex. Sometimes it is the female sex that ripens in the larval state, as in the Aphides *, Stylops, \&c. Sometimes it is the male sex, as in Bonellia, the complementary males of the Cirripedes, the pigmy males of the Rotifera, the male of the salmon and the eel, \&c.

In other cases again the animal presents the two sexes successively with progenesis in one of them. Thus there is protandric progenesis in the Cymothoadian Crustacea, which are males when young, and become females as they grow old and complete their development. The case of old female Gallinaceæ with masculine plumage and instincts, on the contrary, seems to be an imperfect example of protogynic progenesis, since these females have laid eggs when they had still the livery of the young, and have subsequently continued their development and presented the characters of the males, without, however, the production of spermatozoids having been seen.

In extreme cases of female progenesis reproduction even takes place without the assistance of the male element, thus reverting to the primordial agamic form. These cases have been long known under the name of padogenesis. They have been observed in the larvæ of Miastor and Chironomus, and in certain Aphides. The supposed alternation of generations in the Trematoda must also be regarded as a very strongly marked case of female progenesis (pædogenesis), and so also perhaps in other cases still regarded as examples of alternation of generations.

Whenever there is progenesis in a particular type we therefore recognize either momentarily or definitely an arrest of

* According to a very recent note by M. R. Moniez there is in certain Aphides [Coccidæ] progenesis in the male. In this case (Lecanium hesperidum) the male remains rudimentary and in a manner parasitic on the female, like the male of Bonellia ('Comptes Rendus,' February 14, 1887).

Ann. \& Mag. N. Hist. Ser, 5. Vol. xix. 
growth and development; the progenetic animal has consequently the aspect of a sexual larva when compared either with the other sex or with allied forms which do not present the phenomenon of progenesis.

This is in perfect harmony with the principle so well elucidated by Herbert Spencer of the antagonism between genesis and growth and between genesis and development. This antagonism is easily explained if we consider that the materials employed in reproduction cannot serve for the growth of the individual. If it is advantageous to an animal to reproduce without acquiring useless organs, natural selection will soon determine a more and more complete progenesis. Parasitic animals besides that they draw from their host an abundance of nourishment, have no need of a number of organs which serve their free congeners in their relative life. Thus we see that a very great number of parasitic animals are progenetic. The progenetic males of Bonellia and the Cirripedes live as parasites in their females. In certain types (Aphides) progenesis ceases when, the food becoming less abundant, a change of locality may be necesșary.

In short the arrest of development due to progenesis results from a deflection of the nutritive principles to the detriment of the progenetic animal. In the examples of parasitic castration that we have studied the parasite acts, with regard to its host, absolutely the same part as the genital gland of a progenetic type. It diverts, for its own support, a portion of the principles which should have served for the development of the infested animal. The effects produced are also exactly of the same kind.

It is curious to observe to what an extent, in certain cases, the parasite seems to take the place of the absent genital products. The Entonisci occupy precisely the position of the sexual glands of the Decapod Crustacea, and so nearly assume their aspect that we have thought we had before us an hermaphrodite of Carcinus manas, when we had to do with a male bearing a mature Portunion manadis.

The Sacculince and Peltogasters are developed in the very place which the extruded eggs of the crabs and hermit-crabs normally occupy. It is the same with Phryxus paguri and hippolytes. I am even much inclined to believe that, by a very singular reflex action, these parasites produce upon their host the same effect that would be produced by oviposition. The Decapods seem, in fact, to defend their parasites against attacks from without. A crab never frees itself from its Sacculina, even when it has every facility for so doing, and it is only when one places together several Crustaceans bearing 
Rhizocephala that any misfortune happens to the latter. But the same thing takes place if we place together several females loaded with eggs; each one defends her own, but does not hesitate to devour those of her neighbours.

It cannot be objected to this view that the males are infested as well as the females, for these infested males are emasculated and acquire the instincts of the female, like the capons or the unfertile hybrid pheasants, which sit on the eggs and bring up the young* *

\section{VII.}

Besides the intrinsic interest they possess the observations that we have just brought forward have considerable importance from various points of view.

1. In the first place it is probable that ignorance of the modifications produced by the parasite in the external sexual characters of its host has frequently given rise to errors analogous to those of Fraisse, and consequently this diminishes to a certain extent the value of the older statistics with regard to the Rhizocephala, a value which was already not too great from many other considerations.

* We have indicated elsewhere that maternal love has its origin in a simple reflex action which is agreeable to the parent and occurs sometimes in the form of paternal love (fishes), sometimes in that of maternal love properly so called (birds and Mammalia). It is remarkable to find that this explanation was foreseen by Mauduyt as early as 1783 . Thus in the 'Encyclopédie' (Oiseaux i. art. Coq, p. 61), with regard to the attachment of the hen for her eggs and chickens, we read as follows :-

"Is this attachment rational, or is it the sensual product of the contact of the egr? What might lead us to admit the second supposition is that this attachment on the part of the hen does not relate to her own eggs only, but she sits with the same assiduity and perseverance that she shows towards her own eggs upon all those which are given to her, of whatever kind they may be, and even upon inorganic bodies which have no resemblance to eggs but in their form. It is not the colour that deceives her, for I have given a hen to sit the eggs of a Cayenne bird of a very dark greenish-blue colour, and she did not quit them until I took them away."

Mauduyt also perceived that the female psychical characters of castrated males were directly acquired and not the result of the development of a latent instinct. Thus we read (l. c. art. Coq, p. 618) with regard to capons employed in brooding:- " To succeed in this enterprise the belly of the capon to be employed is plucked and rubbed with nettles; he is then shut up in a room with two or three chickens; these young animals, approaching the capon in search of the warmth which they found under their mother, make him experience a coolness which is agreeable, because it moderates the burning sensation that he feels; he lends himself in consequence to their wishes, and in a little time the business of brooding becomes so agreeable to him that he will hardly allow the chickens to escape from under his wings." 
2. As the infested young male crabs are the only ones which become modified in the female direction, it becomes easy to determine the relative proportion of those which have been infested when adult, which could not hitherto be done at all rigorously *. Our statistics, which unfortunately are only founded upon a restricted number of individuals, prove nevertheless that M. Delage was wrong in supposing that infestation in the adult state was quite exceptional. It is, on the contrary, comparatively frequent in Carcinus moenas.

3. As the modification of the external sexual characters is the result of the profound lesion of the genital glands, we must conclude therefrom that the latter already exist at the time of the infestation, or at least that they are in course of formation, which indicates approximately the epoch of the fixation of the parasite.

\section{VIII.}

The fact that a parasite provokes in its host an abnormal development of organs which protect it at the expense of its victim seems at the first glance very exceptional. Nevertheless we must not see in it any teleological argument, but simply a mutual adaptation which is not without analogy with numerous facts of symbiosis (whether between animals of two different species or between animals and plants), facts which form a series of which the case now under consideration may be regarded as an extreme term.

The deformations produced in various plants by the Cecidomyia or the Cynipidæ are absolutely phenomena of the same kind.

An equally curious case is that of the white campion (Melandryum album) infested by Ustilago antherarum. It is well known that the white campion is normally a diœcious plant. The young flower is hermaphrodite. But upon certain plants the ovaries are aborted; on others the stamens remain rudimentary. When the parasitic fungus is developed upon a male plant it fructifies in the stamens; but when it falls upon a female plant it would seem at first that it could not fructify, and this would be so much to the profit of the infested plant. This, however, is not so, for in this case the plant completely develops its rudimentary stamens to enable the parasite to fructify, just as the male Stenorhynchus widens its abdomen to protect the Sacculina Fraissei. Selection acting at once upon the host and upon the parasite has set up a

* The size of the infested individuals does not furnish a sufficient indication from this point of view, as sexual maturity may be produced in individuals of very different sizes. 
modus vivendi between these two creatures; the name of symbiosis has been very justly given to this modus vivendi in those cases in which the two organisms draw a reciprocal profit from their association, and it seems to me desirable even to extend it to the extreme cases that we have been investigating.

\section{XLII.-On new Batrachians from Malacca. By G. A. Boulenger.}

[Plate X.]

Mr. D. F. A. Hervey has presented to the Natural History Museum a collection of Reptiles and Batrachians obtained within a radius of ficty miles from the town of Malacea, which was exhibited in the Straits Settlements Court at the Colonial and Indian Exhibition. The lizards, of which two species were new, have been mentioned in the Appendix to the British Museum Catalogue of Lizards. Of the Batrachians two species are new to the Malay peninsula, viz. Rana laticeps, Blgr., and Microhyla achatina, Boie, and four are new to science and described below.

\section{Rana labialis. (Pl. X. fig. 1.)}

Allied to $R$. chalconota. Vomerine teeth in two oblique series between the posterior borders of the choanæ. Head considerably longer than broad, much depressed; snout long, acuminate, projecting beyond the lip; nostril twice as distant from the eye as from the end of the snout; loreal region deeply concave; the diameter of the eye equals its distance from the nostril; interorbital space a little broader than the upper eyelid; tympanum very distinct, usually about three fourths the diameter of the eye, sometimes quite as large as the eye. Fingers rather slender, first not extending as far as second; toes moderate, three-fourths webbed; tips of fingers dilated into large disks, the diameter of which equals about half that of the tympanum; tips of toes dilated into small disks ; subarticular tubercles moderately developed; two small metatarsal tubercles, outer rather indistinct. Hind limb slender; the tibio-tarsal articulation reaches the tip of the snout or a little beyond. Upper surfaces finely granulate; a glandular lateral fold, distinct only anteriorly; lower surfaces smooth. Brown or purple above, darker on the sides, with rather indistinct darker spots; tympanum chestnut-brown; a 


\section{$2 \mathrm{BHL}$ Biodiversity Heritage Library}

Giard, Alfred. 1887. "XLI.-Parasitic castration, and its influence upon the external characters of the male sex, in the Decapod Crustacea." The Annals and magazine of natural history; zoology, botany, and geology 19, 325-345. https://doi.org/10.1080/00222938709460253.

View This Item Online: https://www.biodiversitylibrary.org/item/55145

DOI: https://doi.org/10.1080/00222938709460253

Permalink: https://www.biodiversitylibrary.org/partpdf/57009

\section{Holding Institution}

Smithsonian Libraries

\section{Sponsored by}

Smithsonian

\section{Copyright \& Reuse}

Copyright Status: Public domain. The BHL considers that this work is no longer under copyright protection.

This document was created from content at the Biodiversity Heritage Library, the world's largest open access digital library for biodiversity literature and archives. Visit BHL at https://www.biodiversitylibrary.org. 